Вісник Дніпропетровського університету. Серія: геологія, географія. 2016. 24 (1), 125-132.

Vìsnik Dnìpropetrovs'kogo unìversitetu. Serîâ geologîâ, geographîâ

Dnipropetrovsk University Bulletin. Series geology, geography. 2016, 24 (1), 125-132.

doi: $10.15421 / 111619$

http://geology-dnu.dp.ua

УДК 624.131 .4

\title{
Визначення впливу мікроструктури на фізико-механічні властивості лесових грунтів Придніпровського регіону
}

\author{
К. О. Самойлич \\ Дніпропетровський національний університет імені Олеся Гончара, Дніпропетровськ, Украӥна, \\ e-mail: kseniya.sam@mail.ru
}

\begin{abstract}
Мета досліджень - уведення нових, більш сучасних методик для виявлення впливу мікроструктури на фізико-механічні властивості лесових грунтів Придніпров'я. Актуальність дослідження полягає у визначенні параметрів мікроструктури дисперсних грунтів, які впливають на цілу низку властивостей фізико-хімічного та механічного характеру. Досліджено фізичні та фізико-механічні властивості, виявлено тип мікроструктури найбільш поширених викопних дофінівського (e $P_{\text {III }} d f$ ), вітачевського (e $P_{\text {III }} v$ ) та лесових удайського (vd $P_{\text {III }}$ ud), дніпровського (vd $P_{\text {II }} d n$ ) грунтів м. Дніпропетровськ. За результатами гранулометричного аналізу методом «Мікроструктура» для кожного 3 грунтів виділено класифікаційний код, розшифрування якого характеризус основні параметри мікроструктури для кожного 3 грунтів. Установлено залежність між типом мікроструктури лесових грунтів та їх просадністю. Виявлено наявність на території м. Дніпропетровськ грунтів агрегованого та змішаного типу мікроструктури, для яких характерний крупнопилуватий змішаний та елементарний тип структурної моделі, агрегати складені різними за розміром частинками 3 переважанням тонкоглинистих і в деяких випадках крупнопилуватих.
\end{abstract}

Ключові слова: мікроструктура, агрегати, лесові грунти, просадкові властивості.

\section{Determination of influence of the microstructure on the physical and mechanical properties of loess soils in Dnieper region}

\author{
K.O. Samoilych \\ Oles Gonchar Dnipropetrovsk National University, Dnepropetrovsk, Ukraine, e-mail: kseniya.sam@mail.ru
}

The aim of my work is to identify, study and analyze of the microstructure of loess soils of Dnieper region. The main task of this work is to determine the composition, structure and properties of loess soils of Prydniprovya, according to new experimental technique that has been used previously in Ukraine. This technique allows to make a forecast of changes of granula composition of loess soils due to their degradation. The subject of the research will be microstructure of loesses and the nature of its structural links, the impact of structural changes on the strength and deformation properties of soils. Microstructureof loess sediments and its change during technogenesis is a factor that affects their deformation behavior. The object of the research will be loess soils, which are the most widespread in the zone of influence of man-made buildings in Dnieper region (for example gullies «Tunnelna», «Zustrichna», «Evpatoriyska»). To be the first in Ukraine in introduction of a new method "Microstructure", to determine the particle size distribution of loess soils of Prydniprovya, to determine the structural strength of the soil and its connection with the peculiarities of the microstructure of loess soils in Dnieper region.

Results shown are the properties of loess soil research that was conducted by yourself as part of state budget theme "Experimental determination and prediction of changes in subsidence of properties (degradation) of loess soils by technogenesis". I investigated the physical and physical-mechanical properties, identified of the most common microstructure type of paleo- $P_{\text {III }} d f$, e $P_{\text {III }} v t$ and of loess soils vd $P_{\text {III }}$ ud, vd $P_{\text {II }}$ dn in Dnepropetrovsk. Particular sized is tribution of loess and paleosoils is determined by a pipette of three ways to preparation the soil analysis (dispersed, standard and aggregate). As a result of particle size analysis method "microstructure" was dedicated classification code fo reach soil. His transcript describes is the basic parameters for each of the microstructure of soils. Found that dofinivskyy horizon $\left(e P_{\text {III }} d\right.$ ) is aggregated type of microstructure, vitachivskyy (e $P_{\text {III }}$ t) - mixed (skeletal-aggregated), and they liy below udayskyy (vd $P_{\text {III }}$ ud) and dneprovskij (vd $P_{\text {II }}$ dn) - mixed (aggregatalskeleted). I revealed the presence of silty the soil mixed with large type and elementary structural model. Aggregates composed of different sized particles with a predominance of fine clay and sometimes coarse silty particles. The dependence between the type of microstructure of loess is the soil and their subsidence. It was found that the type of soils of aggregate subsidence return lower than mixed (aggregatal-skeleted).

Keywords: microstructure, aggregates, loess soils, physical and mechanical properties. 
Вступ. Мета досліджень - уведення нових, більш сучасних методик для виявлення впливу мікроструктури на фізико-механічні властивості лесових грунтів Придніпров'я. Відображено результати самостійного комплексного дослідження властивостей лесових грунтів, що проводилось на базі лабораторії грунтознавства та механіки грунтів Державного агентства «Укравтодор» та НДЛ геології, гідрогеології та геоінформатики НДІ геології в рамках держбюджетної теми «Експериментальне визначення та прогноз змін просадових властивостей (деградації) лесових грунтів при техногенезі». Об'єкт дослідження - дисперсні зв'язні грунти, відібрані зі стінок зриву сучасних зсувів балок Тунельна, Зустрічна, Євпаторійська (м. Дніпропетровськ), розрізу на вододілі балок Тунельна та Зустрічна.

Дисперсні грунти являють собою багатокомпонентні та багатофазні системи, складені мінеральними частинками, пори між якими заповнені повітрям та водою. Кількість і розмір первинних частинок у грунтах визначає його первиннудисперсність. Вторинна, або природна, дисперсність, що характеризується мікроагрегатним складом, враховує в аналізі як первинні, так і вторинні частинки (Ananev, 2005). На первинну дисперсність осадових порід значно впливає їх мінералогічний склад. Чим вищий вміст глинистих мінералів у породі, тим вища iï дисперсність. Лесові грунти - це дисперсні системи, постійний рух яких викликає зміни міцності, водопроникності, набухання, пластичності та інших властивостей, а всі ці властивості залежать від розподілу грунтових фракцій за розміром.

Визначення гранулометричного складу лесових грунтів використовується для виконання багатьох практичних та теоретичних завдань. Різні параметри розміру зерна, такі як медіанний/середній розмір зерна (An et al.,1991; Sun et al., 1998), співвідношення між розмірами зерна, вміст грубозернистої фракції широко використовуються для реконструкції зміни кліматичних умов часів грунтоутворення. Під час інженерно-геологічних вишукувань параметри мікроструктури дисперсних грунтів слугують ознакою літогенезу, який впливає на цілу низку властивостей фізико-хімічного та механічного характеру (Ryaschenko, 2010).

Матеріали та методи досліджень. Першим методом, що дозволив дослідити мікроструктурні особливості лесових порід, був гранулометричний аналіз, за допомогою якого оцінювали кількісний вміст мікроагрегатів (Larionov, 1970). Гранулометричний склад на певному відрізку часу - величина постійна і змінюється тільки за впливу тривалих процесів.
Мікроагрегатний склад породи не $є$ постійним у часі через безперервне утворення у породі та руйнування вторинних частинок.

Важлива особливість структури лесових грунтів - iї висока агрегованість, коли пилуваті та глинисті частинки утворюють ізометричні агрегати 3 розмірами 0,01 - 0,25 мм. Найбільш дрібнодисперсні частинки в лесових породах перебувають у формі макро- та мікроагрегатів, які розрізняються за розміром, водостійкістю та механічною міцністю. Макро- та мікроагрегати виникають та розпадаються за того чи іншого впливу на грунт (розтирання, зміна концентрації електролітів та $\mathrm{pH}$ середовища тощо). Для визначення кількості мікроагрегатів значну роль відіграє характер хімічної, механічної дії на зразок породи. Чим інтенсивніший вплив на грунтову навіску, тим більший вихід дрібнодисперсних частинок.

Гранулометричний склад характеризує граничну дисперсність, а мікроагрегатний відображає ступінь агрегування породи в даних умовах, використовуючи для характеристики структурні зв'язки у породі. Стандартна методика визначення гранулометричного складу грунтів має істотний недолік: вона не дозволяє досягнути максимальної диспергації первинних частинок і не враховує їх постійного динамічного перетворення (Morozov, 1962). Однак, незважаючи на недоліки, результати саме цього методу гранулометричного аналізу є одними з основних характеристик, що дозволяють порівняти будову лесових порід різних регіонів.

С. С. Морозов, класифікуючи лесові грунти за гранулометричним складом, виявив, що в них переважають первинні пилуваті частинки, в той час як у лесоподібних грунтів основними твердими структурними елементами $є$ агрегати (Morozov, 1962). Н. Н. Коміссарова зазначила, що як основні структурні елементи в лесових грунтах виступають складно побудовані глобулярні агрегати (Komissarova, 1977). Разом із Мінервіним А. В. вони розглядали формування глобулярних агрегатів як результат кріогенного роздроблення кристалічного кварцу у процесі накопичення, транспортування та акумуляції матеріалу, наступної аморфізації поверхні кварцу та адсорбції на ній з природних вод, насичених іонами $\mathrm{Ca}^{2+}$ та $\mathrm{HCO}_{3}^{-}$, карбонатної оболонки. Глобулярні агрегати стійкі відносно води структурними елементами лесових порід, тож їх не вивчають 3 точки зору впливу просадності.

Ступінь агрегатизації залежить від кількісного співвідношення основних компонентів, що утворюють грунти - уламкових (кварцу, польових шпатів, різних порід, слюд), глинистих (монтморилоніту, 
гідрослюди, рідше каолініту) та хемогенних (кальциту, іноді сидериту, рідше гіпсу) речовин. Агрегатизація посилюється з глибиною та корелюється з ущільненням породи, зменшенням пористості та просадності (Van, 2011).

Завдяки наявності у лесових грунтах глинястих частинок (0,002 - 0,001 мм) у них може відбуватись процес самоорганізації мікроструктури, зміст якої полягає у самопоновленні (регенерації) зруйнованої механічною дією вихідної структури на мікрорівні (Strokova, Lesovik, Karatsupa, Lyutenko, Yakovlev, 2006).

Механічні елементи, особливо в суглинистих та глинистих грунтах, перебувають в агрегованому стані. В процесі хімічної або механічної обробки до гранулометричного аналізу руйнуються агрегати й відбувається переведення усіх механічних елементів у роздільночастинковий стан. Механічний вплив виконується шляхом розтирання, кип'ятіння, збовтування грунту. Хімічний вплив полягає у заміні поглинутих двовалентних катіонів $\left(\mathrm{Ca}^{2+}\right.$ та $\left.\mathrm{Mg}^{2+}\right)$ на одновалентні $\left(\mathrm{Na}^{+}, \mathrm{Li}^{+}, \mathrm{NH}_{4}^{+}\right)$, які мають великі гідратні оболонки, що спричинює диспергування грунту. За цієї підготовки відбувається найбільш глибока зміна складу грунту, деякі його складові частини розчиняються і не можуть бути враховані в гранулометричному аналізі, тому хімічну підготовку застосовують в особливих випадках.

Завдяки комбінованій дії вапнякового цементу та зв'язаної глини, що складають лесові грунти, вони потрапляють до категорії грунтів із міжзерновими зв'язками (Koliji, Vulliet,Laloui 2010). Муньєз-Кастельбланко, досліджуючи РЕМ-знімки лесових грунтів після нагнітання ртуті у поровий простір під тиском, помітив, що опір мікроструктури неоднорідний, через неправильну позицію глинистих агрегатів. Просадки від змочування відбуваються у тих областях, де $є$ чисті зерна з великими порами коло них. Зони, в яких пористість навколо агрегатів заповнена глинистими частинками, більш стійкі й локально менш чутливі до просадок (Muñoz-Castelblanco, Pereira, Delage,Cui, 2012).

Структурні зв'язки у вологих дисперсних грунтах мають більш складний характер тому, що поруч із молекулярними силами тяжіння виявляються розклинювальні сили тяжіння гідратних оболонок навколо твердих мінеральних частинок, які направлені протилежно молекулярним силам. Крім того, виникають сили взаємодії іонно-електростатичного характеру. Тому у вологих тонкодисперсних грунтах існує молекулярно-іонно-електростатичний зв'язок. В. Т. Трофімов зазначив, що у природних масивах у процесі переходу лесових порід у водонасичений стан утворюються потужні оболонки зв'язаної води, легко руйнуються неводостійкі агрегати, 3 якими пов'язують провальну просадність. У разі тривалого зволоження з плином часу відбувається розпад водостійких агрегатів, що зумовлює уповільнені післяпросадкові деформації лесових товщ (Trofimov, 1999).

На регіональному рівні вже проводились визначення впливу мікрострукутри на просадність лесових грунтів (Часовскіх В. А. та ін.). Проте вони виділяли загальний тип мікроструктури, для визначеного населеного пункту, не враховуючи особливостей, притаманних геологічним горизонтам, що складали лесову товщу цього місця. Дослідники виділили агрегативну, зернисту та зернисто-агрегативну мікроструктури. Агрегативна мікроструктура здатна до повільного доущільнення при сприянні води. Просадка проявляється спокійно, у перший момент спостерігається набуханнягрунтів, а потім уже починається безпосередній розвиток просадкових процесів. У часі він відбувається відносно рівномірно, величина просадкових деформацій від власної ваги грунтів незначна. Цей тип мікроструктури властивий для лесових грунтів м. Дніпропетровськ. Загальний вміст глинистих мінералів у зернистій мікроструктурі менший, ніж в агрегативній. Ірунти мають хорошу несну здатність за умови малої вологості (менше $12-14$ \%), однак за дії води виникають просадкові деформації та руйнування структури через неводостійкість. Процес просідання відбувається з великими швидкостями і має кінцеву величину, у багато разів вищу за просадку грунтів агрегативного типу (переважає у м. Нікополь). У зернисто-агрегативній (проміжній) мікроструктурі просадка відбувається більш інтенсивно, ніж в агрегативній, і менш інтенсивно, ніж у зернистій (м. Запоріжжя) (Chasovskih, Gagarin, Lyubich, Abyizov, Petrov, 1974).

Зміна мікроструктури грунтів у процесі деформування полягає в розпаді агрегатів грунтів, зміщені та перекомпановці частинок, їх переорієнтації та у розвитку дефектів структури - розривів та порушень зв'язків у каркасі грунтів та утворення мікротріщин(Vyalov, Zaretskiy, Maksimyak, Pekarskaya, 1972). I. В. Кареліна та ін. досліджували методи усунення просадкових властивостей лесової основи та підвищення їі міцносних та деформаційних характеристик. Автори дійшли висновків, що за дії динамічних навантажень відбувається максимальне зближення частинок грунту, що супроводжується процесом часткового чи повного руйнування агрегатів та мікроагрегатів (Karelina, Gumirov, Markin, 
2009). Саме для виявлення максимальної кількості агрегатів, які зможуть розпастись, ми застосували гранулометричний аналіз із трьома способами підготовки за методикою «Мікроструктура» (Ryaschenko, 2010). Перевагою цієї методики є розрахунок вмісту частинок відповідного розміру, що дозволяє оперуватирезультатами як динамічною системою.За методикою «Мікроструктура» виділяють агреговану, скелетну та змішану (агреговано-скелетну та скелетно-агреговану) мікроструктури лесових грунтів.За результатами гранулометричного аналізу методом піпетки з трьома способами підготовки визначають коефіцієнт мікроагрегатності, ступінь агрегованості, коефіцієнт свободи, тип мікроструктури та структурної моделі грунтів.

Результати. Для виявлення впливу типу мікроструктури лесових відкладів на їх просадність виконано експериментальні лабораторні дослідження найбільш поширених горизонтів м. Дніпропетровськ. Місця відбору зразків для гранулометричного аналізу: балки Тунельна, Свпаторійська, Зустрічна, вододіл балок Зустрічна та Тунельна. Загалом для характеристики впливу гранулометричного складу на просадність лесових грунтів відібрано 44 значення коефіцієнта
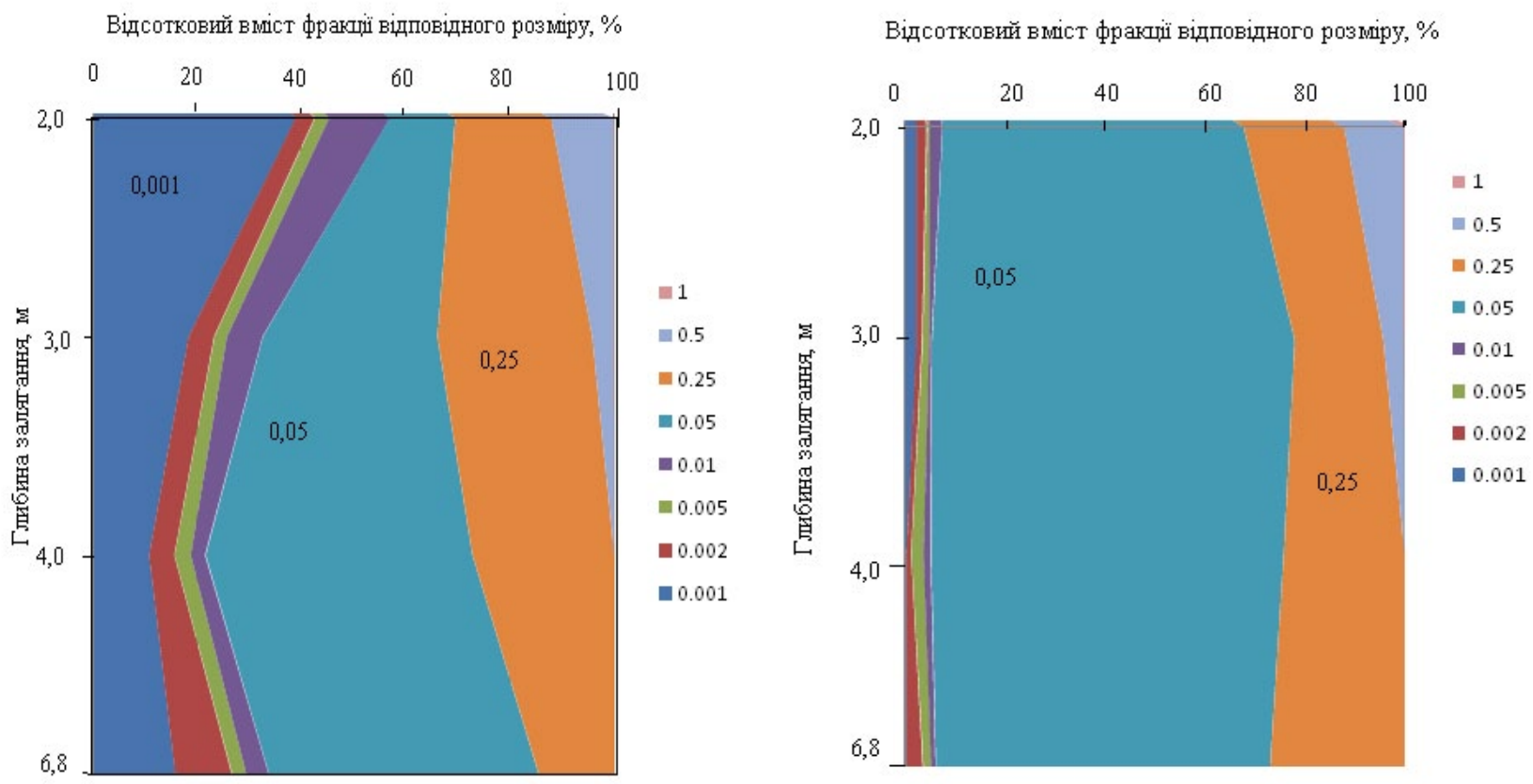

$a$ Відсотковий вміст фракції відповідного розміру, \%

б

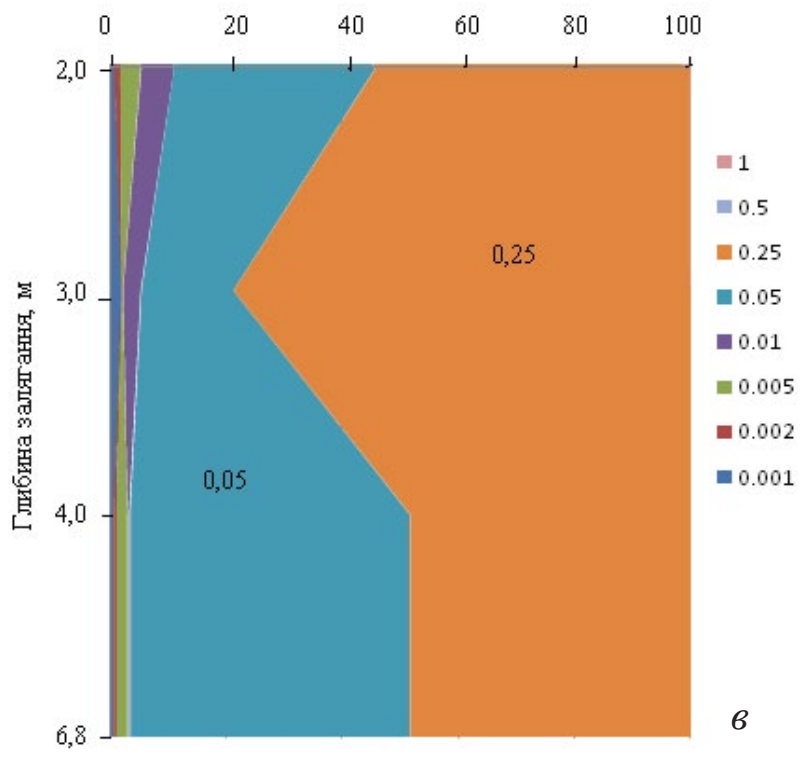

Рис. 1. Розподіл відсоткового вмісту фракцій за: $a$ - дисперсної; $\sigma$ - агрегатної; 6 - стандартної підготовки по глибині 
просадності лесових та викопних грунтів, 200 визначень гранулометричного складу з різними способами підготовки до аналізу. Комплекс досліджень включає в себе визначення фізичних, фізико-механічних властивостей грунтів.

Нижче наведено результати досліджень ділянки, розташованої на вододілі балок Тунельна та Зустрічна, де проводились інженерно-геологічні вишукування для визначення причин просадності 12-поверхової будівлі. Відібрано зразки дофінівського (eP $\mathrm{III} d \mathrm{f})$, вітачівського (e $\left.\mathrm{P}_{\text {III }} \mathrm{vt}\right)$, удайського (vd $\mathrm{P}_{\text {III }} \mathrm{ud}$ ) та дніпровського (vd $\mathrm{P}_{\text {II }} \mathrm{dn}$ ) горизонтів.

Гранулометричний склад лесових та викопних грунтів визначали методом піпетки з трьома способами підготовки грунтів до аналізу (дисперсна, стандартна та агрегатна) (Mokritskaya, Ryaschenko, Akulova, Samoylich, 2013; Ryaschenko, Shestopalov, Akulova, Mokritskaya, Samoylich, 2014; Ryaschenko, 2010). За методикою (Koval, 2001) побудовано гістограми розподілу відсоткового вмісту фракцій трьома способами підготовки по глибині. Розподіл на горизонти прийняли умовно, маючи за мету наочно відобразити різницю по виходу частинок відповідного розміру.

За дисперсної підготовки максимально руйнуються мікроагрегати і збільшується відсотковий вміст фракцій розмірами $<0,001$ мм, 0,001 - 0,002 мм, 0,002 $-0,005$ мм, 0,005 - 0,01 мм. За агрегатної підготовки зруйновані тільки водонестійкі агрегати, тож максимальний вміст мають фракції розміром 0,05 - 0,25 мм та 0,25 - 0,5 мм. За стандартної підготовки проходить частковий розпад мікроагрегатів, переважний вміст також мають фракції розміром 0,05-0,25 мм та 0,25 - 0,5 мм, проте вміст тонкодисперсних частинок трохи більший, ніж за агрегатної підготовки. Вміст крупних фракцій поступово зменшується знизу вгору по розрізу (і відповідно зростає вміст дрібних частинок). Цей факт свідчить про послаблення гідродинамічної активності з часом іiї формування. Тож для визначення часткового/повного руйнування агрегатів та мікроагрегатів рекомендовано проводити гранулометричний аналіз трьома способами підготовки зразків.

Результати проведених лабораторних досліджень наведено нижче. За результатами гранулометричного аналізу методом «Мікроструктура» для кожного 3 грунтів виділено класифікаційний код, розшифрування якого характеризує основні параметри мікроструктури для кожного з грунтів (Ryaschenko, 2010).

Для запису коду мікроструктури використовують такі позначення: $\mathrm{M}^{9}$ - загальний вміст грубо- та тонкоглинястих частинок $(<0,002$ мм) за даними стандартної гранулометріі; $\mathrm{M}^{11}$ - загальна кількість крупно- та дрібнопилуватих частинок (0,05 - 0,002 мм) за даними стандартної гранулометрії; A - загальна кількість агрегатів; $\mathrm{A}^{1-5}$ - кількість агрегатів, розміром $1,00-0,25 ; 0,25-0,05 ; 0,05-0,01 ; 0,01-0,002$; $0,002-0,001$ мм; $\mathrm{M}^{2 \mathrm{~A}}-\mathrm{M}^{6 \mathrm{~A}}$ - кількість частинок у складі агрегатів, розрахована для фракцій 1,00 - 0,25;0,25 - 0,05; 0,05 - 0,01;0,01 - 0,002;0,002 $-0,001 ;<0,001$ мм. $\mathrm{F}^{2}-\mathrm{F}^{6}-$ коефіцієнти вільності, розраховані для фракцій $1,00-0,25 ; 0,25-0,05$; $0,05-0,01 ; 0,01-0,002 ; 0,002-0,001 ;<0,001$ мм; $\mathrm{M}^{8}$ - загальна кількість (первинних і у складі агрегатів) частинок $<0,002$ мм.

Дофінівський горизонт (e $\left.\mathrm{P}_{\text {III }} \mathrm{df}\right)$, глибина відбору проби 2,0 м, представлений суглинками сірувато-коричневого кольору, легкими, місцями піщанистими. Природна вологість $11-20$ \%, число пластичності 9 ч. од., щільність грунту $1,45-1,60$ г/ $\mathrm{cm}^{3}$, щільність грунтових частинок $-2,55$ г/ $\mathrm{cm}^{3}$. Коефіцієнт неоднорідності за дисперсної підготовки - 60; за агрегатної - 2,5; за стандартної - 35,8.

$M^{9} 3,04 M^{11} 46,32$ A 50,28 [A $\left.A^{2} 6,59 A^{3} 43,68\right] M^{4 A} 11,62$ $\mathrm{F}^{4} 20,86 \mathrm{M}^{5 \mathrm{~A}} 3,38 \mathrm{~F}^{5} 39,9 \mathrm{M}^{6 \mathrm{~A}} 35,27 \mathrm{~F}^{6} 6,58 \mathrm{M}^{8}$ 43,39.

Розшифровка. Суглинок пилуватий, мікроструктура - агрегативна, тип структурної моделі крупнопилувата (переважають крупнопилуваті структурні елементи) змішана. Агрегати складаються 3 тонкоглинястих $\left(\mathrm{F}^{6} 6,58\right)$ і дрібнопилуватих $\left(\mathrm{F}^{4} 20,86\right)$, у меншому ступені - грубоглинястих $\left(\mathrm{F}^{5} 39,9\right)$ частинок. Реальна глинястість суглинків 43,39 \% за рахунок агрегативної мікроструктури.

Вітачівський горизонт (e $\left.\mathrm{P}_{\mathrm{III}} \mathrm{vt}\right)$, глибина відбору 3,0 м - суглинки світло-буро-коричневі з червоним відтінком. Природна вологість 15 - $17 \%$, число пластичності 7 ч. од., щільність грунту 1,79 г/ $\mathrm{cm}^{3}$, щільність грунтових частинок $-2,64$ г/ $\mathrm{cm}^{3}$. Коефіцієнт неоднорідності за дисперсної підготовки - 27; за агрегатної - 2,35; за стандартної - 46,94.

$\mathrm{M}^{9} 2,02 \mathrm{M}^{1130,77}$ A 28, 17 [A $\left.\mathrm{A}^{4} 5,40 \mathrm{~A}^{5} 2,58 \mathrm{~A}^{6} 20,19\right]$ $\mathrm{M}^{3 \mathrm{~A}} 25,93 \mathrm{~F}^{3} 71,55 \mathrm{M}^{2 \mathrm{~A}} 2,24 \mathrm{~F}^{2} 92,12 \mathrm{M}^{8} 26,41$.

Розшифровка. Суглинок пилуватий, мікроструктура - скелетно-агрегована, тип структурної моделі крупнопилувата (переважають крупнопилуваті структурні елементи) елементарна. Агрегати складаються з крупнопилуватих частинок $\left(\mathrm{F}^{3} 71,55\right)$. Реальна глинястість суглинків $26,41 \%$ за рахунок скелетно-агрегованої мікроструктури.

Удайський горизонт (vd $\mathrm{P}_{\text {III }} \mathrm{ud}$ ), глибина відбору 4,0 м - лесоподібний супісок світло-палевий, легкий, вапняковистий. Природна вологість $13 \%$, 
число пластичності 4 ч. од., щільність грунту 1,79 г/ $\mathrm{cm}^{3}$, щільність грунтових частинок $-2,63$ г/ $\mathrm{cm}^{3}$. Коефіцієнт неоднорідності за дисперсної підготовки - 21,3; за агрегатної - 1,9; за стандартної - 34,15.

$\mathrm{M}^{9} 2,15 \mathrm{M}^{11} 18,93$ A $21,11\left[\mathrm{~A}^{2} 9,82 \mathrm{~A}^{3} 11,29\right] \mathrm{M}^{4 \mathrm{~A}}$ $1,96 \mathrm{~F}^{4} 60,43 \mathrm{M}^{5 \mathrm{~A}} 2,10 \mathrm{~F}^{5} 31,05 \mathrm{M}^{6 \mathrm{~A}} 17,04 \mathrm{~F}^{6} 2,90 \mathrm{M}^{8} 20,60$.

Розшифровка. Супісок пилуватий, мікроструктура - агрегативно-скелетна, тип структурної моделі крупнопилувата (переважають крупнопилуваті структурні елементи) змішана. Агрегати складаються 3 тонкоглинястих $\left(\mathrm{F}^{6} 2,90\right)$ і грубоглинястих $\left(\mathrm{F}^{5} 31,05\right)$, у меншому ступені -дрібнопилуватих $\left(\mathrm{F}^{4} 60,43\right)$. Реальна глинястість суглинків 20,60\% за рахунок агрегативно-скелетної мікроструктури.

Дніпровський горизонт (vd $\left.\mathrm{P}_{\mathrm{II}} \mathrm{dn}\right)$, глибина відбору 6,8 м - лесоподібний супісок, жовто-палевий, легкий, вапняковистий. Природна вологість $6-7$ $\%$, число пластичності 6 - 7 ч. од., щільність грунту

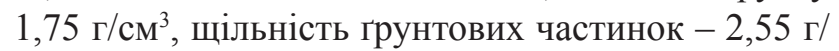
$\mathrm{cm}^{3}$. Коефіцієнт неоднорідності за дисперсної підготовки - 20; за агрегатної - 1,75; за стандартної - 29.

$\mathrm{M}^{9} 4,17 \mathrm{M}^{11} 47,29$ A 21,09 [A $\left.6,69 \mathrm{~A}^{3} 14,40\right] \mathrm{M}^{4 \mathrm{~A}} 2,24$ $\mathrm{F}^{4} 56,91 \mathrm{M}^{5 \mathrm{~A}} 3,90 \mathrm{~F}^{5} 31,66 \mathrm{M}^{6 \mathrm{~A}} 14,95 \mathrm{~F}^{6} 6,30 \mathrm{M}^{8} 21,65$.

Розшифровка. Супісок пилуватий, мікроструктура - агрегативно-скелетна, тип структурної моделі крупнопилувата (переважають крупнопилуваті структурні елементи) елементарна. Агрегати складаються 3 тонкоглинястих $\left(\mathrm{F}^{6} 6,3\right)$ і грубоглинястих $\left(\mathrm{F}^{5} 31,66\right)$, у меншому ступені -дрібнопилуватих $\left(\mathrm{F}^{4} 56,91\right)$ частинок. Реальна глинястість суглинків $21,65 \%$ за рахунок агрегативно-скелетної мікроструктури.

Тож за результатами гранулометричного аналізу грунтів вододілу балок Тунельна та Зустрічна методом «Мікроструктура» виділено класифікаційний код, розшифровка якого характеризує основні параметри мікроструктури для кожного $з$ грунтів. Дофінівський горизонт (e $\mathrm{P}_{\text {III }} \mathrm{df}$ ) має агрегований тип мікроструктури, вітачівський (e $\left.\mathrm{P}_{\mathrm{III}} \mathrm{vt}\right)$ - змішаний (скелетно-агрегований), а нижчезалягаючі удайський (vd $\left.\mathrm{P}_{\text {III }} \mathrm{ud}\right)$ i дніпровський (vd $\left.\mathrm{P}_{\text {II }} \mathrm{dn}\right)$ - змішаний (агреговано-скелетний). Для досліджуваних грунтів характерний крупнопилуватий змішаний (e $\mathrm{P}_{\text {III }} \mathrm{df}$, e $\left.\mathrm{P}_{\text {III }} \mathrm{vt}, \mathrm{vd} \mathrm{P}_{\text {III }} \mathrm{ud}\right)$ та елементарний (vd $\mathrm{P}_{\text {II }} \mathrm{dn}$ ) типи структурної моделі, агрегати складені різними за розміром частинками з переважанням тонкоглинястих (e $\mathrm{P}_{\text {III }} \mathrm{df}, \mathrm{vd} \mathrm{P}_{\text {III }} \mathrm{ud}$, vd $\left.\mathrm{P}_{\text {II }} \mathrm{dn}\right)$ і в деяких випадках крупнопилуватих (e $\mathrm{P}_{\text {III }}$ vt).

Із рисунка 2 видно, що загальна кількість агрегатів та частинок (первинних і в складі агрегатів) iз глибиною зменшується. Загальний вміст крупно- та дрібнопилуватих частинок $(0,05-0,002$ мм)

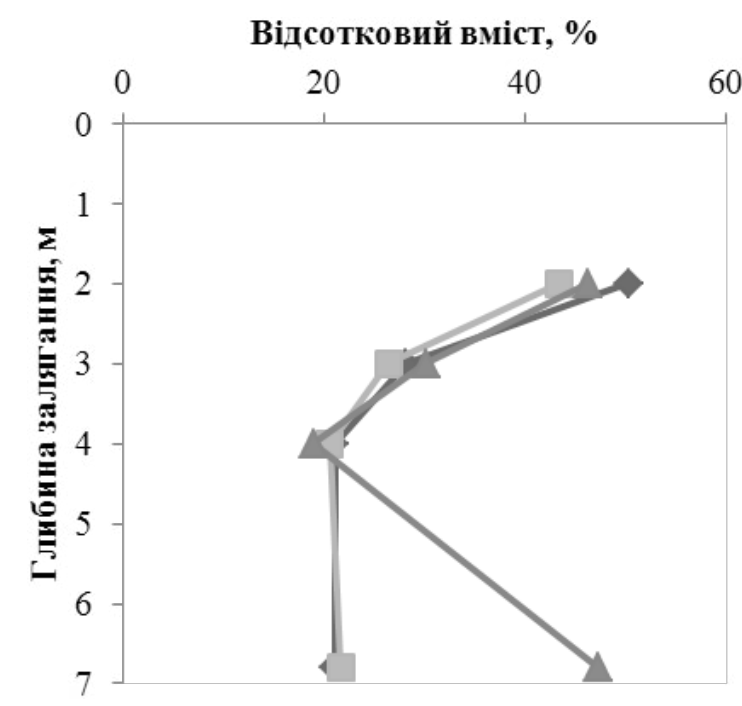

Рис. 2. Розподіл загальної кількості агрегатів та частинок по глибині. Вміст крупно- та дрібнопилуватих частинок $(0,05-0,002$ мм $)$

$\rightarrow$ - загальна кількість агрегатів; --- загальна кількість частинок (первинних і в складі агрегатів); - - - загальний вміст крупно- та дрібнопилуватих частинок $(0,05$ - 0,002 мм) за даними стандартної гранулометрії

теж зменшується з глибиною, проте починає своє збільшення для дніпровського горизонту. Для е $\mathrm{P}_{\text {III }} \mathrm{df}$ Ta vd $\mathrm{P}_{\text {II }} \mathrm{dn}$ грунтів характерні більш високий вміст крупно- та дрібнопилуватих частинок $(0,05-0,002$ мм), а руйнування частинок саме цього розміру скоріше за все $\epsilon$ причиною значних просадкових деформацій.

У компресійних приладах системи «Гідропроект» за методикою «двох кривих» визначено характеристики просадності грунтів для монолітів непорушеної структури в інтервалі навантажень 0,05 - 0,6 МПа. (Samoylich, 2015).

За результатами компресійних випробувань для грунтів агрегованого (e $\left.\mathrm{P}_{\mathrm{III}} \mathrm{df}\right)$ та агреговано-скелетного (vd $\mathrm{P}_{\text {II }} \mathrm{dn}$ ) типів мікроструктури побудовано графік залежності коефіцієнта просадності від тиску $\varepsilon_{s l}=\mp($ Р) (рис. 3).

Процес ущільнення грунтів агрегованого типу мікроструктури на ділянці A - A' відбувається лінійно, на ділянці A' - A" спостерігається нерівномірне затухання. Це може бути спричинене руйнуванням агрегатів розміром $0,25-0,05$ мм за дії граничних навантажень. Процес ущільнення грунтів змішаного (агреговано-скелетного) типу мікроструктури відбувається лінійно, стрімко, на всьому інтервалі навантажень, без затухання. Грунти агрегованого типу мають менші показники просадності, ніж змішано- 
го (агреговано-скелетного). Для е $\mathrm{P}_{\text {III }}$ df ta vd $\mathrm{P}_{\text {II }} \mathrm{dn}$ грунтів характерний більш високий вміст крупнота дрібнопилуватих частинок $(0,05-0,002$ мм), а руйнування частинок саме цього розміру скоріше за все $€$ причиною значних просадкових деформацій.

\section{P, МПа}

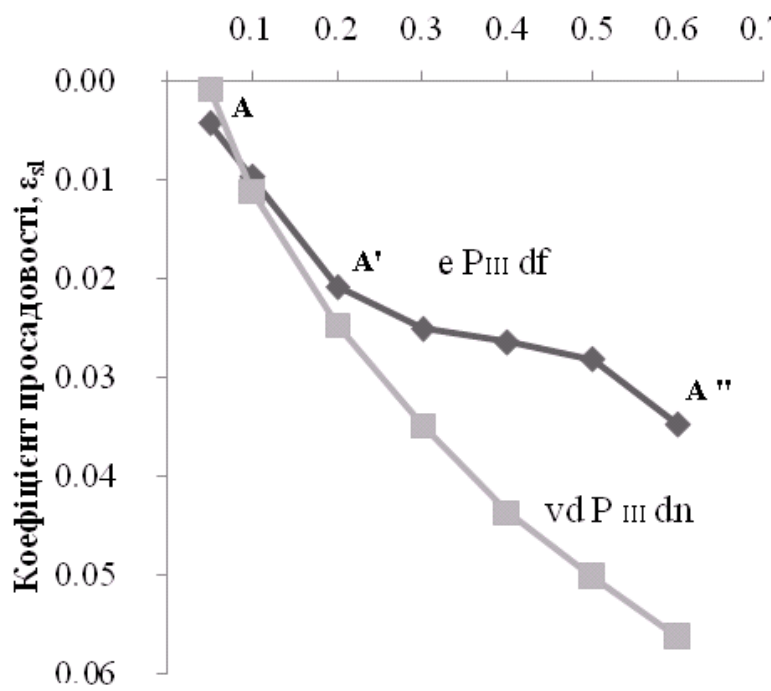

Рис. 3. Графік залежності коефіцієнта просадності від тиску $\varepsilon_{\mathrm{sl}}=\mathrm{f}(\mathrm{P})$ для грунтів агрегованого (e $\left.\mathrm{P}_{\mathrm{III}} \mathrm{df}\right)$ та агреговано-скелетного ( $\mathrm{vd} \mathrm{P}_{\mathrm{II}} \mathrm{dn}$ ) типу мікроструктури забудованої території вододілу

Висновки. Отже, у процесі дослідження мікроструктури лесових та викопних грунтів Придніпровського регіону отримано класифікаційні коди мікроструктури, за якими встановлено, що дофінівський горизонт (e $\mathrm{P}_{\text {III }} \mathrm{df}$ ) має агрегований тип мікроструктури, вітачівський (e $\left.\mathrm{P}_{\text {III }} \mathrm{vt}\right)$ - змішаний (скелетно-агрегований), а нижчезалягаючі удайський (vd $\left.\mathrm{P}_{\text {III }} \mathrm{ud}\right) \mathrm{i}$ дніпровський (vd $\left.\mathrm{P}_{\mathrm{II}} \mathrm{dn}\right)$ - змішаний (агрегованоскелетний). Грунти агрегованого типу мають менші показники просадності, ніж змішаного (агрегованоскелетного).

Результати досліджень показали, що тип мікроструктури впливає на просадність лесових відкладів. На даному етапі досліджень одержані висновки не суперечать відомим раніше результатам, тому вирішено продовжити дослідження гранулометричного складу, щоб у подальшому з'явилась можливість застосовувати дані гранулометричного аналізу як прогнозні характеристики властивостей лесових грунтів.

\section{Бібліографічні посилання}

An, Z.S., Kukla, G., Porter, S.C., Xiao, J.L., 1991. Late Quaternary dust flow on the Chinese Loess Plateau. Catena 18, 125-132.
Ananev, V.P., Potapov, A.D., 2005. Inzhenernaya geologiya: Ucheb. dlya stroit. spets. vuzov [Engineering geology : Proc . for the building . specialist. universities]. M .: Higherwksc. (in Russian)

Chasovskih, V.A., Gagarin, P.A., Lyubich, L.G., Abyizov, A.G., Petrov, O.B., 1974. Strukturnyie osobennosti lessovyih Gruntov i uprochnenie ih v rezultate uplotneniya. [The structural features of loess soils and strength eningthemas a result of compaction]. Questions Hydrogeology and Engineering Geology of Ukraine. Geotechnical and hydrological forecasts. Publishing house «Budivelnik», Kiev. 18 - 19 (in Russian)

Chmshkyan, A.V., 2012. Sovershenstvovanie metodov rascheta prosadochnyih deformatsiy [Perfection of methods of calculation of subsidence deformation] Engineers Don Gazette Issue number 4-2, volume 23. (in Russian)

Karelina, I.V., Gumirov, M.A., Markin, V.B., 2009. Izmenenie mikrostruktury lessovykh gruntov pod vozdejstviem dinamicheskikh nagruzok [Changing the microstructure of clayey soils under load] Journal "Mining" 3, p. 43. (in Russian)

Kemp, R.A., 1999. Micromorphology of loess-paleosol sequences: arecord of paleoenvironmental change. Catena 35, 181-198.

Koliji, A., Vulliet, L., Laloui, L., 2010. Structural characterization of unsaturated aggregated soil. Canadian Geotechnical Journal 47 (3). 297 - 311.

Komissarova, N.N., 1977. Formirovanie strukturyi I teksturyi prosadochnyih lessovyih porod (na primere Minusinskogo mezhgornogo progiba) [Formation of structure and texture of subsidence of loess rocks (for example, Minusinsk intermontanetroughs)] Abstract. Dis. Cand.G.Min. Sciences. - M.: MSU, 1977. - 26 p. (in Russian) Koval, S.A., 2001. Kompyuternaya obrabotka rezultatov granulometricheskogo analiza psammitov I ih genetieskaya interpritatsiya [Computer processing of the results particle size analysis psammitov and their genetic interpretation] Vestnik SSU Ser. Geology, 12. (in Russian)

Mokritskaya, T.P., Ryaschenko, T.G., Akulova, V.V., Samoylich, K.A., 2013. Mikrostruktura lessovyih otlozheniy Srednego Pridneprovya na primere dneprovskogo gorizonta (g. Dnepropetrovsk) [The microstructure loessial deposits on the example of the Middle Dnieper Dnieper horizon (Dnepropetrovsk)] Problems and experience of engineering protection of urban areas and the preservation of heritage interms of geoecological risk: Proceedings of the International Scientific Conference. C K.: Phoenix, 227 - 230. (in Russian)

Morozov,S.S., 1962. Izmenenie v sostave i svoistvah lessovih porod $\mathrm{v}$ zavisimosti ot nahozhdeniya $\mathrm{v}$ razlichnih prirodnih zonah [Changes in the composition and properties of loess rocks, depending on location invarious natural zones] Bulletin MSU. Ser. Geology, 4. - S.13 - 24.(in Russian)

Muñoz-Castelblanco J. A., J. M. Pereira, P. Delage and Y. J. Cui, 2012. The water retention properties of a natural unsaturated loess from Northern France. Géotechnique, $62(2), 95-106$. 
Osipova, M.A., 2007 Analiz izmeneniya strukturnoy prochnosti lessovyih Gruntov Priobskogo plato v zavisimosti ot koeffitsienta poristosti pri razlichnyih pokazatelyah tekuchesti [Analysis of changes in the structural strength of loess soils $\mathrm{Ob}$ plateau depending on the porosity coefficient at various flow rates] Polzunovsky Bulletin number 1, 2, $75-77$. (in Russian)

Ryaschenko, T.G., 2010. Regionalnoe Gruntovedenie (Vostochnaya Sibir) [Regional Soil (Eastern Siberia)] Irkutsk: Earth Crust SBRAS.(in Russian)

Ryaschenko, T.G., Shestopalov, V.M., Akulova, V.V., Mokritskaya, T.P., Samoylich, K.A., 2014. Osobennosti mikrostroeniya i fraktalnoy strukturyi lessovyih otlozheniy Srednego Pridneprovya i yugaVostochnoy Sibiri [Feature of the microstructure and the fractal structure of the Middle Dnieper and south of Eastern Siberia loess deposits] Proceedings of the higher educational establishments: Geology and Exploration. 5. 37 - 42.. (in Russian)

Samoylych, K.O., 2015. Analiz zminy prosidnykh vlastyvostey lesovykh gruntiv Prydniprovs'koho rehionu [The analysis of subsidence loess soil properties Dnipro region] Proceedings of the Third International Forum of Students and Young Scientists/ed.: M. count.. Polyakov (Chairman) and others. D.: DNU. 442 - 443. (in Ukrainian)

Strokova, V.V., Lesovik, R.V., Karatsupa, S.V., Lyutenko, A.O., Yakovlev, E.A., 2006. Mikrostruktura tehnogennyih glinistyih Gruntov, kak factor tehnogennogo litogeneza [Microstructure anthropogenic clay soils, as a factor of technogenic Lithogenesis] The success of modern natural science number 6, 52 - 54 (in Russian)

Sun, Y., Lu, H., An, Z., 2006. Grain size of loess, palaeosol and Red Clay deposits on the ChineseLoess Plateau: Significance for understanding pedogenical teration and palaeomonsoon evolution. Palaeogeography, Palaeoclimatology, Palaeoecology 241. 129 - 138

Sun, D.H., An, Z.S., Shaw, J., Bloemendal, J., Sun, Y.B., 1998.Magnetostratigraphy and paleoclimatic significance of late Tertiary aeolian sequences in the Chinese Loess Plateau. Geophys. J. Int.134, 207 - 212.

Trofimov, V.T., 1999. Prosadochnost' leyssoviyh porod [The genesis of subsidence of loess rocks] M.: MSU.(in Russian)

Van, A.V., 2011. Postsedimentatsionnyie protsessyi V formirovaniy prosadochnyih svoystv lessovyih porod. [Postsedimentary processes in the formation of subsidence properties of loess rocks] Interekspo Geo-Sibiria. 2. (in Russian)

Vyalov, S.S., Zaretskiy, Yu.K., Maksimyak, R.V., Pekarskaya, I.K., 1972. Kinetika strukturnyih deformatsiy i razrusheniya glin [Kinetics of structural deformation and destruction of clays] Inthebook: Proceedings XIII International Conf. soils mechanics and foundation. M. 13 -23. (in Russian)

Wen, L.J., Lu, H.Y., Qiang, X.K., 2005. Changes in grain-size andsedimentation rate of the Neogene Red Clay deposits along the Chinese Loess Plateau and implications for the palaeowindsystem. Sci. China, Ser. D: Earth Sci. 48, 1452-1462. 